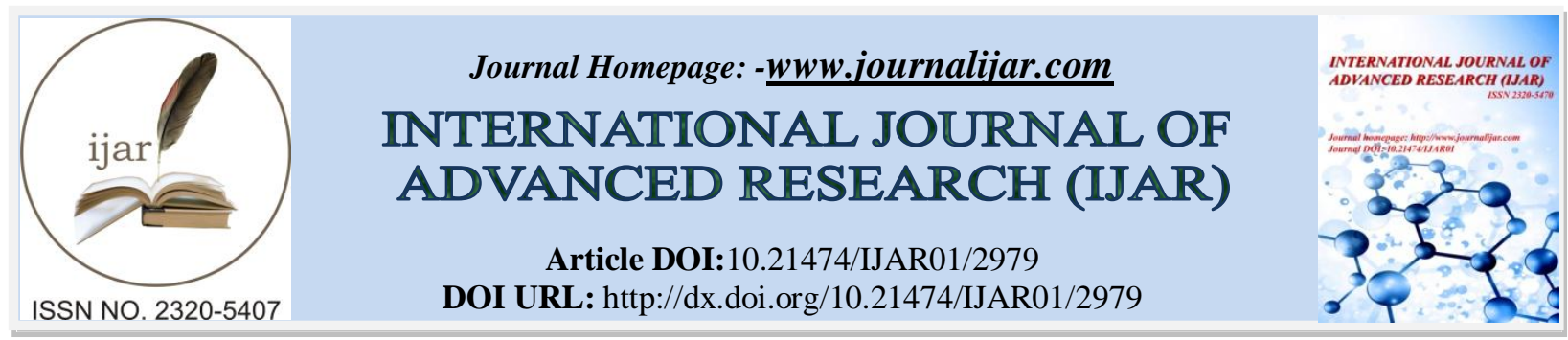

RESEARCH ARTICLE

\title{
EFFECT OF LIGHT ON VENOM OF BUNGARUSCAERULEUS (INDIAN COMMON KRAIT)
}

Anju.

Lecturer of Microbiology, Department of Biotechnology, MVGU, Jaipur.

\section{Manuscript Info}

Manuscript History

Received: 26 November 2016

Final Accepted: 27 December 2016

Published: January 2017

Key words:-

Radiation, proteins, ionising, non-

ionising, toxicity, immunogenic

\begin{abstract}
In case of snake envenomation the only therapy available is antiserum inoculation. The antiserum is raised in horses. The toxicity of the venom reduces the life of a horse. Moreover when a horse is given a dose of venom with adjuvant, it brings a lot of discomfort to the horse with local necrosis at the site. Because the proteins are integral part of snake venom an effort has been made in the present study to see the effect of electromagnetic spectrum on venom of Bungaruscaeruleusor Indian common krait. Proteins are in general sensitive to radiation. After irradiation there is change in a number of physical and chemical properties of the proteins. It may further produce rearrangement of the protein. It decreases antigenicity of the proteins as is shown in present study where we can observe the loss of immunogenic components when exposed to UV, infra-red rays and to direct sunlight.
\end{abstract}

Copy Right, IJAR, 2016,. All rights reserved.

\section{Introduction:-}

The common four species ofsnakesresponsible for casualities due to envenomation belong to two families of snakes: elapidae and viperidae. The venom of elapidae is neurotoxic and that of viperidae is cadiotoxic. The Indian common krait and cobra belong to elapidae family. The proteins are integral part of the snake venom. Itis a mixture of thousands of different peptides, proteins, enzymes and chemicals. Most common snake venom enzymes include acetylcholinesterases, L-amino acid oxidases, serine proteases, metalloproteinases, and phospholipases-A 2. These enzymes are necessary for a venom to be toxic. Higher catalytic efficiency, thermal stability, and resistance to proteolysis make these enzymes attractive models for every researcher (Kang et al., 2011).

Visible light, ionizing and non-ionizing radiations are part of electromagnetic radiations and are used vastly in medical, diagnostic and research fields (Angela Newing, 1999). These electromagnetic waves carry energy. Our eyes can perceive only a small portion of the electromagnetic spectrum which we know as visible light. Ultraviolet (UV) light is the portion of the electromagnetic spectrum between visible light and $\mathrm{x}$-rays, with a wavelength of 100 to $400 \mathrm{~nm}$. The red end of the electromagnetic spectrum is low frequency, low energy and long wavelength, whereas the blue end is high frequency, high energy and short wavelength. The visible light is in the middle of the electromagnetic spectrum. Infra-red rays are also present in electromagnetic spectrum felt in everyday life by human beings as heat. It is invisible like UV rays and is of longer wave length as compared to the visible light starting from the red edge of the visible spectrum at $700 \mathrm{~nm}$ to $1000000 \mathrm{~nm}$. The UV light is used to expose the venom. It is generally with a wavelength of 100 to $400 \mathrm{~nm}$. It is the portion of electromagnetic spectrum lying in between visible light and x-rays. Sources of UV radiation are sun as a natural source, lasers, and number of medical and research instruments like dental polymerising equipment. Shorter the wave length more damage caused by it to the substrate (Akram\&Rubock 2005). 
Since ionizing radiations are efficient in altering structure and properties of proteins and enzymes, they have been used to attenuate toxins of animal origin. The results are favourable as there is decrease in toxicity of the toxin under experiment(Esmat, 2003).

Gamma radiation is a potential toolused to detoxify a venom. It either slows down or stop enzymatic activities of venom. Gamma radiations work directly on the biomolecules or indirectly when the venom is in solution form.

These radiations act on the biomolecules in venom solution directly or indirectly. The direct process where radiations acts directly on the enzymatic proteins and indirectly when the venom is in solution. In indirect way water radiolysis products too help in interaction and affect the action of radiations on protein biomolecules. In the present study also the venom has been used in solution form to observe the effect of radiation.

\section{Aim and Objective:-}

- The present study is an attempt to observe the effect of visible and invisible light on the toxicity and immunogenicity of the venom of Bungaruscaeruleus(Indian common krait).

- This may further help to select the wave length of light suitable to reduce the toxicity of venom, to inoculate in horses or other experimental animals, for raising antivenom sera.

- This will further help in reducing local discomfort to the animal.

\section{Materials and Methods:-}

\section{Material:-}

1. Venom: the common krait or B.caeruleusvenom used in this study was obtained from Central Research Institute Kasauli\& the normal toxicity of this venom was checked before starting these experiments.

2. Slides- Glass slides of $20 \times 5 \mathrm{~cm}$ were used for immunodiffusion tests.

\section{Methodology:-}

Experimental method was used in the present study. Throughout experiments, the toxicity was checked by inoculating aliquotes intravenously in mice and $\mathrm{LD}_{50}$ was calculated. For immunodiffusion test, gel diffusion was used, followed by staining of slides.

Effects of light were observed by keeping equal quantities of venom in liquid state in different conditions like complete darkness, in day-light, sun-light, UV light and in infra-red rays.In all the above mentioned experiments the toxicity tests were observed after every 7 days interval for 28 days and immunological components by immunodiffusion tests.

\section{Results:-}

The venom showedreduction in toxicityby storing the venom in complete darkness after 28 days. The reduction in toxicity in day light is still marked. The venom was rendered more or less non-toxic by exposing the solution to direct sun light for three hours/day for 28 days. Immunodiffusion test also proved that 2 components of venom were lost in day light as compared to control venom. In case of complete darkness one component was lost.

The effect of invisible light i.e. UV rays, infrared rays was studied here. The results indicated that there is marked reduction of toxicity of Indian krait venom when the venom solution is exposed to U.V light .The toxicity is also reduced on exposure to infra-red rays. The effect of invisible light on krait venom's toxicity was confirmed by immunodiffusion test which showed that there was loss of 2 components of venom in both the situations.

Table 1:- Effect of visible light on venom ofBungaruscaeruleus (Indian common Krait)

\begin{tabular}{|c|c|c|c|c|c|}
\hline \multirow{2}{*}{$\begin{array}{l}\text { Interval after } \\
\text { start (days }\end{array}$} & \multirow{2}{*}{$\begin{array}{c}\text { Visible change } \\
\text { if any }\end{array}$} & \multirow{2}{*}{$\begin{array}{l}\text { Venom control } \\
\text { solution in N.S }\end{array}$} & \multicolumn{3}{|c|}{ LD $_{50}$ of solution of venom exposed to } \\
\hline & & & $\begin{array}{l}\text { Complete } \\
\text { darkness }\end{array}$ & Day light & Sunlight \\
\hline 0 & No change & 1.6384 & 1.6384 & 1.6384 & 1.6384 \\
\hline 7 & No change & 1.6384 & 1.6384 & 2.048 & 64 \\
\hline 14 & $\begin{array}{l}\text { Turbidity sun } \\
\text { light }\end{array}$ & 1.7660 & 2.585 & 4 & 100 \\
\hline
\end{tabular}




\begin{tabular}{|c|c|c|c|c|c|}
\hline 21 & $\begin{array}{c}\text { Turbidity sun } \\
\text { light }\end{array}$ & 1.7810 & 3.710 & 9.571 & 121.8 \\
\hline 28 & Turbidity in all & 1.8130 & 4.595 & 10.24 & 312.5 \\
\hline $\begin{array}{l}\text { No. of immunogenic components } \\
\text { after 28 days }\end{array}$ & 7 & 6 & 4 & 4 \\
\hline
\end{tabular}

Table 2:- Effect of invisible light on venom of Bungaruscaeruleus (Indian common Krait)

\begin{tabular}{|c|c|c|c|c|c|}
\hline \multirow{2}{*}{$\begin{array}{c}\text { Venom } \\
\text { exposed to }\end{array}$} & \multicolumn{4}{|c|}{$L_{50}$ of venom exposed } & \multirow{2}{*}{$\begin{array}{c}\text { Immunogenicity(no. } \\
\text { of components) }\end{array}$} \\
\hline & I & II & III & Mean & \\
\hline $\begin{array}{c}\text { Unexposed } \\
\text { (control venom) }\end{array}$ & 1.6384 & 1.7810 & 1.8130 & 1.7441 & 7 \\
\hline UV rays & 180.0 & 198.2 & 198.4 & 192.2 & 5 \\
\hline Infrared rays & 183.3 & 185.1 & 185.1 & 184.8 & 5 \\
\hline
\end{tabular}

Table 3:- Effect of light on toxicity and immunogenicity on venom ofBungaruscaeruleus(Indian common Krait)

\begin{tabular}{|c|c|c|c|c|c|c|c|}
\hline \multirow{2}{*}{ Property } & \multicolumn{7}{|c|}{ Venom Exposed to } \\
\cline { 2 - 8 } & \multicolumn{2}{|c|}{ Unexposed } & UV Rays & $\begin{array}{c}\text { Infra-red } \\
\text { Rays }\end{array}$ & $\begin{array}{c}\text { Complete } \\
\text { darkness }\end{array}$ & Day light & Sunlight \\
\hline \multirow{3}{*}{\begin{tabular}{l} 
Toxicity \% \\
\cline { 2 - 8 }
\end{tabular}} & $\mathrm{R}$ & 100 & 0.90 & 0.94 & 100 & 66.67 & 66.67 \\
\hline $\begin{array}{c}\text { Immunogenicity } \\
\%\end{array}$ & $\mathrm{R}$ & 100 & 99.10 & 99.06 & 0 & 33.33 & 33.33 \\
\cline { 2 - 8 } & $\mathrm{L}$ & 0 & 47.14 & 57.14 & 100 & 44.87 & 1.47 \\
\hline
\end{tabular}

Abbreviations: R - Retained, L - Lost

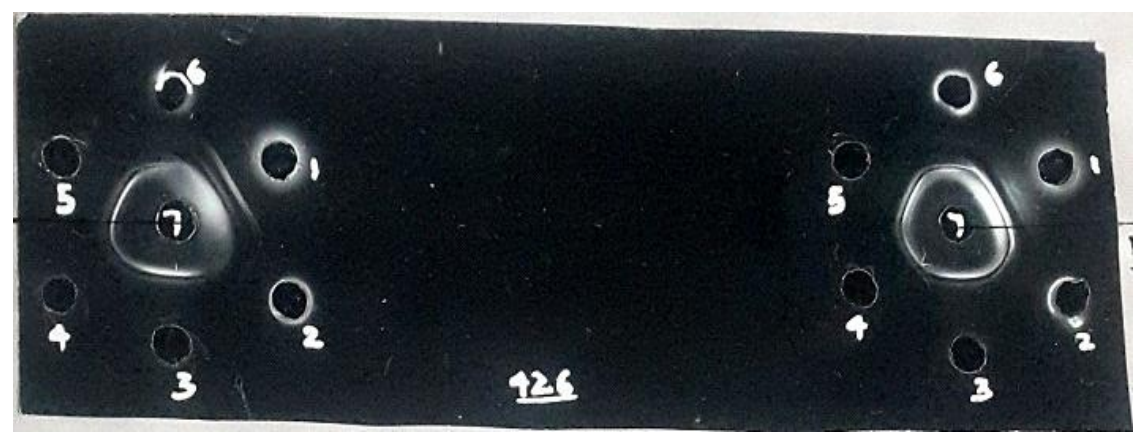

Figure:- Effect of light on immunogenicity on venom of Bungaruscaeruleus

1- Untreated venom

3 - Venom exposed to Sun light

5- Venom kept in dark
2-- Venom exposed to UV light

4-- Venom exposed to Day light

6- Venom exposed to Infra-red light

The results of venom kept for 7 days did not produce any visible change in the venom kept in darkness, day light or sunlight. After 14 days some turbidity appeared in vial kept in sunlight. After 28 days the turbidity appeared in all the venom vials kept in dark, day light and sunlight.

The toxicity also showed fall in the case of day light and sun light. The venom became non-toxic when kept in sun light and lethal dose was calculated as 312.5 microgram in mice by intravenous route of inoculation. Daylight reduced the lethality of venom when kept for 28 days, and the $\mathrm{LD}_{50}$ was calculated as 10.24 microgram. Complete darkness condition had effect on the $\mathrm{LD}_{50}$ and it was calculated as 4.595 micrograms. The venom lost one immunogenic component in complete darkness and 2 components were lost in day light and sunlight condition after 28 days.

The venom exposure to infra-red rays and UV rays showed that the toxicity was lost upto $99.10 \%$ in infra-red while it was lost up to $99.06 \%$ in venom solution exposed to ultra-violet. Loss in toxicity was $33.33 \%$ in day light as well as sun light, but immunogenicity was lost up to $55.13 \%$ in day light and $98.53 \%$ in case of sun light. 


\section{Discussion:-}

UV radiation and infra-red radiations are widely used in research labs, medical labs, antisera labsto control the bacterial and viral infection to avoid contamination and to keep the inoculating area completely free of microbes (Pauland Christina, 2006). The day light has capacity to kill partially the micoorganisms, whereas the sunlight makes the area exposed totally sterilised. This knowledge is used in hospitals and homes to sterilise the woolllens and beddings along with other fomites.It is because of the bacteriostatic or bactericidal property of light on the protein content of the microbes.

In the present study the knowledge of action of light on the proteins has been used to observe the effect of light on the venom from Bungaruscaeruleus. This is done to try to turn venom into the venoid/toxoid so as to reduce the toxicity of venom while retaining immunogenicity. This process can also make the venom less toxic to the animals in which antivenom is to be raised. The results of the present study indicated that venom is almost denatured by the action of day light, sunlight, UV rays and infra-red rays. The venom kept in darkness showed slight fall in toxicity with retention of 6 immunogenic components.

In the present study ionizing radiations like UV rays and non-ionizing radiations like infra-red rays have been used to observe the effect on Indian common krait venom along with visible part of the electromagnetic spectrum. The basic difference between these two types is the amount of energy they possess. Ionizing radiation has higher energy and has the ability to break chemical bonds, causing ionization of atoms and production of free radicals that can result in biological damage. Non-ionizing radiation doesn't have enough energy to cause ionization but disperses energy through heat and increased molecular movement (Zaider and Rossi, 1985; Hall, 2000).

The venom has been used in aqueous solution because irradiation of aqueous solutions induces chemical and structural alterations in proteins and peptides related to an attenuation or abolishments of biological activity and interferences in immunological properties. When the venom was subjected to visible and invisible spectrum of light it showed decrease in toxicity and immunogenicity. Whether the wave length of light was small as in UV light, large as in infra-red case or the middle spectrum that is direct sun light, it denatured the proteins and the immunogenicity was lost along with toxicity. The study also served to characterise the venom of Bungaruscaeruleus but further study is needed.

Proteins are in general sensitive to radiation and that is why the effect is so enhanced on venom when exposed to UV, infra-red rays and to direct sunlight. After irradiation there is change in a number of physical and chemical properties of the proteins. It may further produce rearrangement of the protein (Antoni, 1973). It decreases antigenicity of the proteins as is shown in present study, where we can observe the loss of immunogenic components when exposed to UV, infra-red rays and to direct sunlight. Generally as the wave length of radiation decreases the energy emitted by it increases that means the UV rays which have shorter wavelength as compared to infra-red are more lethal for the proteins but both types ofrays are showing same result in the present study. Toxicity and immunogenicity are affected equally by these radiations.

\section{Acknowledgement:-}

Theauthor is thankful to the Biotechnology Department of MVGU for their kind help. The author is thankful to Dr Mukesh Sharma for his guidance. Without his knowledge and expertise the work could not have been possible. 


\section{References:-}

1. Kang TS, Georgieva D, Genov N, et al (2011). Enzymatic toxins from snake venom: structural characterization and mechanism of catalysis. FEBS J, 278, pp.4544-76.

2. Angela Newing (1999). Treatment with ionizing radiation. Light, visible and invisible, and its Medical applications, World Scientific, pp. 57-89. (Internet citation on 14 Nov, 2016). https://books.google.com>books>about

3. Akram M and Rubock P. (2015). Environmental Health\& Safety. Working Safely with Ultraviolet Radiation. Policy and Procedures, 2015, Journal of Emerging Investigators. Columbia University Health Sciences Division

4. Esmat A. Shaban (2003). Influence of ionizing radiation on Cobra (Najahaje) and Cerastescerastes venoms: Toxicological and Immunological aspects. The Egyptian Journal of Hospital medicine Vol.13, pp. 99-111.

5. Paul J. Meechan1 and Christina Wilson1 (2006), Use of Ultraviolet Lights in Biological Safety Cabinets: A Contrarian View. Applied Biosafety, 11(4) pp. 222-227

6. Zaider, M. and Rossi, H.H., (1985). Dual radiation action and the initial slope of survival curves. Radiat. Res. Suppl., 8, pp. 568 - 576.

7. Hall, E.J., (2000): A radiation biological looks to the future. Int. J. RadiatOncol., Biol. Phys., 46, 1 - 2.

8. Antoni, F., (1973). The effect of ionizing radiation on some molecules of biological importance. Manual on Radiation Sterilization of Medical and Biological Material. Tech. Rep. Series, No. 149, 13 - 21. 